Kabul Tarihi: 08.02.2019

\title{
Türkiye'de Turizm İşletmeciliği Lisans Programları Müfredatlarında Teknoloji Dersleri
}

\section{Technology Courses in Curriculums of Tourism Management Undergraduate Programs in Turkey}

\author{
Dr. Öğr. Üyesi Ferkan KAPLANSEREN \\ Dokuz Eylül Üniversitesi \\ İşletme Fakültesi \\ E-posta: ferkan.kaplanseren@deu.edu.tr
}

\author{
Öğr. Gör. Dr.Manolya AKSATAN \\ Dokuz Eylül Üniversitesi \\ İşletme Fakültesi \\ E-posta: manolya.aksatan@deu.edu.tr
}

\section{Öz}

Turizm endüstrisinin teknolojiyi yönetebilen ve karar verme sürecinde kullanabilen, nitelikli insan kaynağı intiyacı günden güne artmaktadır. Bu çalışmanın amacı, Türkiye'de turizm işletmeciliği lisans programlarının müfredatlarında yer alan teknoloji derslerini belirlemektir. Çalışmada 38 turizm işletmeciliği programının müfredatında yer alan 163 ders belirlenmiş ve içerikleri analiz edilmiştir. Dersler, otomasyon sistemleri, bilgi teknolojileri, elektronik disiplinler ve yönetim bilişim sistemleri şeklinde sınıflandırılmıştır. Bulgular üzerine akademisyenler ile görüşmeler yapılmış ve içerik analizi yöntemi ile incelenmiştir. Görüşmelerin bulguları, teknoloji derslerinin çeşidi, sayısı ve niteliği üzerinde etkili olan kısıtları, programlara dair beklentileri ve önerileri göstermektedir. Bu çalışma, müfredat planlama sürecine ve nitelikli insan kaynağı yetiştirme çalışmalarına katkı sağlamaktadır.

Anahtar Kelimeler: Turizm, Teknoloji, Müfredat.

\section{Abstract}

The need of qualified human resource that can manage the technology and use it in decision making process in tourism industry is increasing day by day. The purpose of this study is to determine the technology courses indicated in the curriculums of tourism management undergraduate programs in Turkey. In this study, 163 courses in the 38 curriculums of tourism management undergraduate programs were determined and the contents were analyzed. The courses were classified as automation systems, information technologies, electronic disciplines and management information systems. Interviews on the findings were conducted with the academicians and examined by the content analysis method. The findings of the interviews present the constraints that are effective on type, number and quality of technology courses, the expectations and the suggestions on programs. This study contributes to the curriculum planning process and the studies to raise the qualified human resource.

Key Words: Tourism, Technology, Curriculum. 


\section{Giriş}

Turizm, dünyanın hızla büyüyen sektörleri arasında yer almaktadır. Turistik ürün ve hizmetlere yönelik talebin dinamik yapısı ve özellikleri, bu hizmetleri sunan organizasyonların intiyaçlarını etkilemektedir. Turizm işletmeleri emek yoğun özelliktedir (Amoah ve Baum, 1997). Dolayısıyla, nitelikli iş gücüne sahip olmak, işletmelerin etkili ve verimli bir şekilde faaliyet gösterebilmeleri açısından temel bir ihtiyaçtır. Sektör, yönetici ve çalışanlarının çok donanımlı olmasını talep etmektedir (Daniel ve diğ., 2017).

Yapay zeka, iş zekası, bulut bilişim, robotik sistemler ve endüstri 4.0 gibi toplumu, ekonomiyi ve işletmeleri sürekli değişim içerisinde tutan günümüz konuları ve turizm sektörünün dinamik yapısı değerlendirildiğinde, bu yapının oluşumuna neden olan temel faktörlerden birinin teknoloji olduğu açıkça görülmektedir. Bilgi teknolojileri sektörün gelişimine ve faaliyetlerine önemli bir katkıda bulunmaktadır (Lashley ve Rowson, 2005). Bununla birlikte, bazı durumlarda işletmelerin bilgi teknolojilerini kullanması ve yönetmesi oldukça zor hale gelmektedir. İşletmelerin teknoloji uyumunu gerçekleştirebilmesi için bu teknolojilere yatırım yapmaları yeterli değildir. Teknolojinin getirdiği faydalardan yararlanabilmeleri için gereksinim duyulan teknolojileri entegre edebilecek, yönetebilecek ve kullanabilecek yönetici ve çalışanlara intiyaç bulunmaktadır.

Teknolojik gelişmelerin etkilemediği bir turizm endüstrisi düşünmek mümkün değildir (Buhalis, 1998; Buhalis, 2008). Turizm sektöründe yer alan işgücüne gerekli bilgi ve becerileri kazandırmada ise turizm eğitimi veren kurumların büyük sorumluluğu bulunmaktadır. Bu nedenle, turizm alanında eğitim veren üniversite programlarının, göz önünde bulundurması gereken önceliklerden biri, sektörün teknoloji eğilimleri konusundaki beklentilerini anlayabilmek ve cevap verebilmektir (Amoah ve Baum, 1997). Turizm eğitiminin tasarlanması sürecinde teknoloji eğilimlerinin ve sektörün intiyaçlarının dikkatlice belirlenmesi, eğitim planlarının ve ders içeriklerinin bu doğrultuda hazırlanması gerekmektedir. Dersler aracıı̆ğıyla öğrencilerin iş yaşamlarında kullanacağı bilgi teknolojilerine aşinalığı sağlanmalıdır (Lashley ve Rowson, 2005). Bilgi teknolojileri dersleri, ağırlama öğrencilerinin iş hayatlarında başarılı yöneticiler olabilmeleri için önem taşımaktadır (Bilgihan ve diğ.,2014; Zehrer ve Mössenlechner, 2009).

$\mathrm{Bu}$ çalışmanın amacı, Türkiye'deki Turizm İşletmeciliği lisans programlarının ders planlarında yer alan teknoloji konulu dersleri ve içeriklerini incelemek, mevcut durumu belirlemek ve geliştirmeye yönelik önerilerde bulunmaktır. Araştırmanın bulguları, müfredatların güncellenmesine ve geliştirilmesine yönelik çalışmalara katkı sağlayacaktır. Devam eden bölümlerde öncelikle literatür taramasına yer verilecek, araştırmanın yöntemi ve bulguları açıklanacak, son bölümde ise sonuç ve öneriler tartışılacaktır.

\section{Literatür}

Son yıllarda araştırmacılar oldukça ilgi çekici olan "teknoloji" ve "eğitim" konularını iki farklı açıdan irdelemektedir. Bunlardan ilki teknolojinin bir araç olarak öğrenme ve öğretme sürecine dâhil edilmesidir (örn. Hsu, 2012; Penfold, 2009; Lee ve diğ.,2017). Diğer gruptaki çalışmalar ise turizm öğrencilerine öğretilen ya da öğretilmesi gereken bilişim teknolojileri üzerinedir (örn. Cheung ve Law, 2000; Lashley ve Rowson, 2005; Bilgihan vd. 2014). Bu çalışma, içerik açısından ikinci gruba dâhildir. Turizm programları ve teknoloji konularını araştıran çalışmaların; ders planlarının içeriği ve 
derslerin türü (örn. Chathoth ve Sharma, 2007; Buhalis ve O'Connor, 2001) ile öğrencilerin ve/veya sektör temsilcilerinin beklentileri ve algıları (örn. Elliot ve Joppe, 2009; Özen ve Zengin, 2015) üzerinde odaklandığı anlaşılmaktadır.

Literatürde, turizmcilerin sahip olması gereken teknoloji bilgisi ve yetenekleri üç başlık altında sınıflandırımaktadır. Bunlar, endüstriye özgü uygulamalar (1), son kullanıcı uygulamaları (2) ve kavramsal ve stratejik odaklı uygulamalar (3) şeklindedir (Buhalis ve O'Connor, 2001'den aktaran Bilgihan ve diğ.,2014:325). Bahsedilen ilk teknoloji grubu, turizm endüstrisinde intiyaç duyulan önbüro programları benzeri teknolojileri içermekte, ikinci grupta temel ofis yazılımları gibi teknolojiler bulunmakta, son grupta ise veri madenciliği gibi, stratejik karar verme sürecinde önemli rol oynayan teknolojiler yer almaktadır. Turizm ve ağırlama endüstrisi lisans programlarında bilgi teknoloji öğretiminde çok farklı yöntem ve yaklaşımlar kullanılmakta ve bu farklılıklar eğitimcilerin sahip olduğu altyapıya göre çeşitlilik göstermektedir (Buhalis, 1998). Ağırlama ve turizm yönetimi programlarının ders içeriklerini inceleyen Chathoth ve Sharma (2007), işletme ile ilgili dersler arasında "bilgi sistemleri", ağırlama ve turizm yönetimi ile ilgili dersler arasında ise "hizmet organizasyonlarında teknoloji" derslerinin olduğunu belirlemiştir.

Bir başka çalışmada Lashley ve Rowson (2005) benzer bir yaklaşım ile kişisel yetenekler (1), sektöre özgü operasyonel yetenekler (2) ve sektöre özgü yönetimsel yetenekler (3) şeklinde bir ayrım yapmaktadır. Kişisel yetenekler temel bilgi teknolojileri kullanımını ifade etmekte, operasyonel yetenekler otel rezervasyon sistemleri, acente sistemleri, yiyecek-içecek maliyetlendirme sistemleri gibi sektöre özgü teknoloji kullanım becerisine karşılık gelmekte ve son olarak, yönetimsel yetenekler maliyet kontrol sistemleri, bütçeleme, web sitesi tasarımı gibi teknolojileri içermektedir.

Bilgihan ve arkadaşlarının (2014: 328-332) araştırma bulguları, ağırlama okullarından mezun öğrencilerin bilmesi gereken en önemli altı bilgi teknolojisi becerisinin "elektronik tablo programları kullanımı (örn. Microsoft Excel), "e-posta sistemleri", "kelime işlemci programları kullanımı (örn. Microsoft Word)", "etkin yapıda veri sunumu", "satış noktası sistemleri" ve "bilgisayarlar ile sayısal veri analizi (örn. SPSS)" olduğunu göstermektedir. Aynı çalışmada mezunların, "bilgisayar ağı yaratma ve sürdürme", "proje yönetimi yazılımı", "ses kaydı ve biçimlendirme", "besin analizi yazılımı", "video kaydı ve biçimlendirme" konularında performanslarının yöneticiler tarafından düşük olarak algılandığı ortaya çıkmıştır.

Turizm sektörünün kendine özgü dinamik yapısı program içeriklerinin ve ders planlarının da değişikliklere göre güncellenmesini gerektirmektedir (Cheung ve Law, 2000; Busby ve Huang, 2012). Cecil ve Krohn (2012)'un bulguları turizm bölümlerinin ders planlarının hazırlanması ve güncellenmesi süreçlerinde sektörden gelen geribildirim ve önerilerin mutlaka göz önünde bulundurulması gerektiğinin önemini hatırlatmaktadır. Ancak, turizm eğitimi üzerine yapılan bir başka çalışma, eğitimin zayıf noktaları ve sorunları arasında turizm sektöründe yaşanan gelişmelerin ders içeriklerine yansımadığını ve bilgi teknolojileri eğitim ve uygulama imkânlarının yetersiz olduğu yönünde bir algı olduğunu ortaya koymuştur (Akoğlan Kozak, 2009).

Bilgihan ve arkadaşları (2014) sektör yöneticilerinin, ağırlama endüstrisi mezunlarından bekledikleri bilgi teknolojileri yetkinliği ile mezunların bilgi teknolojileri performanslarını karşılaştırmıştır. Bu çalışmanın sonucunda en temel beklentiler ile en yüksek performans gösterilen alanların birbiriyle örtüştüğü ancak tüm beklentileri içeren genel bir değerlendirme yapıldığında, performansların beklentilerin altında kaldığı belirlenmiştir. 
Teknolojinin gelişmesine bağlı olarak üniversitelerde okutulan derslerin adları ve/veya içerikleri ya zamanla değişim göstermiş ya da yeni dersler okutulmaya başlanmıştır. Genel olarak, "Temel Bilgi Teknolojileri", "Temel Bilgisayar Uygulamaları" isimleriyle başlayan bu sürece, "Yönetim Bilişim Sistemleri" dersleriyle devam edilmiş daha sonra bölümlere özgü olarak bu ders isimleri, bölüm isimleriyle tamamlanarak "Turizm İşletmelerinde Bilişim Sistemleri", "Seyahat İşletmelerinde Bilişim Sistemleri" gibi dersler oluşturulmuştur. Yakın geçmişte elektronik ticaret ve elektronik iş kavramının gelişmesiyle birlikte ortaya "E-Turizm" ve "Turizmde E-Pazarlama" gibi dersler çıkmış ve ders içerikleri turizme özgü olarak belirlenmiştir. Mobil ticaret, alan tabanlı ticaret, yaygın ticaret kavramları ise genellikle "elektronik" kelimesiyle başlayan derslerin içerikleri altında yer bulmuştur. E-turizm konusundaki dersleri müfredatlarına ekleyerek turizmde öncü rol oynayan üniversiteler arasında Bournemouth, Cornell gibi üniversitelerin olduğunu belirleyen Elliot ve Joppe (2009)'un bulguları, endüstri uzmanlarının, turizm öğrencilerinin e-turizm ortamlarını yönetebilme becerilerine sahip olmalarını beklediklerini ortaya koymuştur. Bu beceriler arasında problemlerin çözülebilmesi ve işletme stratejileri geliştirilebilmesi için veri analizi yapabilmek, dağıtım yönetimi sistemleri ve merkezi rezervasyon sistemleri arasındaki bağlantıyı anlayabilmek, web'de getiri yönetimi, satış ve müşteri hizmetleri yönetimi becerilerini anlayabilmek, web site tasarımı ve yönetimi yapabilmek, çevrimiçi pazarlama kavramlarını anlayabilmek bulunmaktadır.

Program müfredatlarının, sektörün intiyaçlarının yanı sıra coğrafi, ekonomik ve sosyo-kültürel intiyaçlar doğrultusunda da farklılıklar göstermesi mümkündür. Dolayısıyla, tüm intiyaçları karşılayan standart bir program müfredatından bahsetmek zordur. Türkiye'de, teknoloji temelli turizm işletmeciliği derslerinin müfredata ne ölçüde entegre edildiğini anlamak bu açıdan önem taşımaktadır.

\section{Araştırmanın Yöntemi}

Bu çalışmanın iki aşaması bulunmaktadır. İlk aşamada hem nitel hem de nicel bir yaklaşım kullanılmıştır. Öncelikle Türkiye'de devlet ve vakıf üniversitelerinde fakülte düzeyinde lisans eğitimi veren turizm işletmeciliği bölüm müfredatları ele alınmıştır. Yapılan araştırmalar sonucunda, Türkiye'de 34 üniversitede toplam 54 turizm işletmeciliği lisans programı olduğu bilgisine ulaşılmıştır. Yüksek Öğretim Kurulu'nun Lisans Atlası bu listenin oluşturulmasında temel kaynak olmuştur (Yükseköğretim Kurulu, 2018). Yapılan araştırmada iki üniversitede hem Türkçe hem de İngilizce program bulunduğu belirlenmiştir. Bu programların müfredatları da hesaplamalara dâhil edilmiştir. Buna ilaveten yapılan web taramasında iki üniversitenin daha turizm işletmeciliği bölümleri olduğu öğrenilmiştir. Böylece, turizm işletmeciliği bölümü olan toplam üniversite sayısı 36'ya, lisans programı sayısı ise 56'ya ulaşmıştır. Mevcut programlardan 17'sinde ikinci öğretim programı bulunmaktadır. Bu çalışmada, hem gündüz hem de ikinci öğretimde ders veren bölümlerin yalnızca gündüz öğretim planları sayılara yansıtılmıştır. Yeni kurulan bir programın müfredatına dair hiçbir bilgiye ulaşılamadığından hesaplamalara dâhil edilmemiştir. Araştırmanın örneklemini Türkiye'nin 27 farklı şehrinde, 35 üniversitede yer alan 38 fakülte düzeyindeki Turizm İşletmeciliği lisans programı oluşturmaktadır.

Araştırmanın ilk aşamasında içerik analizi yöntemi kullanılmıştır. Yıldırım ve Şimşek (2006: 227) içerik analizini "birbirine benzeyen verileri belirli kavramlar ve temalar çerçevesinde bir araya getirmek ve bunları okuyucunun anlayabileceği bir biçimde düzenleyerek yorumlamak" şeklinde açıklamaktadır. Bu araştırmada resmi web sitelerinde yer alan bilgiler toplanmıştır. Çalışmada doğrudan teknoloji ile ilişkili dersler listelenmiştir. Daha sonra temel ve alt kodlar oluşturulmuş, dersler bu kodlar 
altında sınıflandırılmıştır. Çalışmaya konu olan programlardaki derslere dair ilk analizler, 26 Mart ve 3 Nisan 2018 tarihleri arasında gerçekleştirilmiştir. Bölüm dışı seçimlik dersler müfredatların bir parçası olmadığı için sayılara yansıtılmamıştır. Dersler sınıflandırıldıktan sonra dağılımları incelenmiştir.

Ders sınıflandırması yapılırken, araştırmacıların karşılaştıkları en büyük zorluklardan ilki bazı programların müfredatlarına ve derslerin içeriklerine ulaşılamaması, çok sınırlı bilgiye ya da güncellenmemiş bilgiye ulaşılması olmuştur. Diğer bir zorluk ise bazı ders isimleri ile içeriklerinin üniversitelere göre değişiklik göstermesi şeklindedir. Bir programın web sayfasında ders planları sayfası açılmadığından ve başlıkların altında bilgi bulunmadığından, müfredat yerine dönemlik ders programları incelenmiştir.

Araştırmacılar araştırmanın güvenilirliği sağlamak için ikinci analiz sürecine geçmiş ve 16 Nisan ve 19 Nisan 2018 tarihleri arasında kendi uzmanlıkları doğrultusunda katkı sunarak ortak bir analiz gerçekleştirilmiştir. Bu aşamada araştırmacılar dersleri birlikte incelemiş ve kategorileri karşılaştırmıştır. 2-4 Mayıs 2018 tarihlerinde, dersler son bir kez daha kontrol edilmiş ve sınıflandırma işlemini tamamlamıştır.

Çalışmanın ikinci aşaması nitel olarak yapılandırılmıştır. 6 Haziran 2018 ila 8 Şubat 2019 tarihleri arasında, turizm işletmeciliği alanında görev yapan 14 akademisyen ile birinci aşamanın bulguları üzerine yarı yapılandırımış, derinlemesine ve yüz yüze görüşmeler gerçekleştirilmiştir. Akademisyenler kolayda örneklem metodu ile belirlenmiştir. Bununla birlikte, bulguları zenginleştirebilmek için farklı ünvanlara sahip, teknoloji konusuna aşina olan veya olmayan, idari görevi olan veya olmayan, farklı yaş gruplarından kişilerin örnekleme dâhil edilmesi sağlanmıştır. Görüşme sayısı dokuza ulaştığında veri doygunluğuna ulaşılmış, üç görüşme daha yapılmıştır. Toplamda üç profesör, üç doçent, bir öğretim görevlisi, beş araştırma görevlisi ve iki doktor araştırma görevlisi ile görüşülmüştür. Katılımcılar, demografik özellikleri, çalıştıkları kurumdaki pozisyonları, akademik geçmişleri, çalışma deneyimleri (yurt içi ve yurt dışı) gibi unsurlar açısından birbirinden farklı özelliklere sahiptir. Görüşme yapılan dört öğretim elemanı teknoloji ile doğrudan ilişkili en az bir ders yönetmektedir. İki katılımcı ise bu tür dersleri asiste etmektedir. Görüşme yapılan araştırma görevlilerinin tamamı teknolojiye yatkınlığı fazla olarak bilinen $Y$ kuşağındandır. Bu çalışmada araştırma etiği çerçevesinde katılımcıların isimleri yerine temsilen bir kod numarası kullanılmıştır. Bulgular bölümünde katıımcı görüşleri aktarıırken, esas cümlelerde hiçbir değişiklik yapılmamıştır. Anlatım bozukluklarını ortadan kaldırmak ve cümlelerin anlaşılırlığını kolaylaştırmak için araştırmacılar tarafından eklenen kelimeler ise köşeli parantez "[ ]" ile gösterilmiştir.

Katılımcılara yöneltilen sorular hazırlanırken, literatürde yer alan çalışmalar esas alınmış (örn. Cheung, ve Law, 2000; Bilgihan ve diğ., 2014), önceki aşamanın bulguları kullanılmıştır. Tüm görüşmeler, izin alındıktan sonra ses kayıt cihazı ile kaydedilmiştir. Görüşmeler 15 ila 34 dakika arasında sürmüştür. Ses dosyaları, araştırmacılar tarafından yazıya dökülmüş, iki araştırmacı tarafından ayrı ayrı analiz edilmiştir. Daha sonra analiz sonuçları karşılaştırılmıştır. Bir sonraki bölümde çalışmanın bulgularına yer verilecektir.

\section{Bulgular}

Bu araştırmanın bulguları iki başlık altında değerlendirilecektir. İlk başlık altında, turizm işletmeciliği lisans programlarının ders planlarına ait sayısal bulgular açıklanacaktır. İkinci başlıkta, akademisyenler ile yapılan görüşmelerin bulgularına yer verilecektir. 


\subsection{Ders Müfredatlarına Dair Bulgular}

$\mathrm{Bu}$ çalışmada eğitim programlarına ait dersler belirli kategoriler altında sınıflandırılırken, literatür bölümünde bahsedilen Buhalis ve O'Connor (2001) ile Lashley ve Rowson (2005)'ın çalışmalarındaki kategoriler göz önünde bulundurulmuş ve Türkiye'deki turizm işletmeciliği programlarında yer alan derslerin kendine has özellikleri çerçevesinde bir sınıflandırma yapılmıştır.

Araştırma, 38 Turizm İşletmeciliği lisans programı müfredatında yer alan ve teknoloji konusuna doğrudan temas eden toplam 163 ders üzerine yapılmıştır. Bu dersler, bilgi teknolojileri (BT), yönetim bilişim sistemleri (YBS), elektronik disiplinler (ED) ve otomasyon sistemleri (OS) olmak üzere dört temel başlık altında sınıflandırıımıştır. Grafik 1'de kategorilere dair verilerin dağılımı gösterilmektedir.

\section{Grafik 1: Ders Kategorilerine Göre Verilerin Dağılımı}

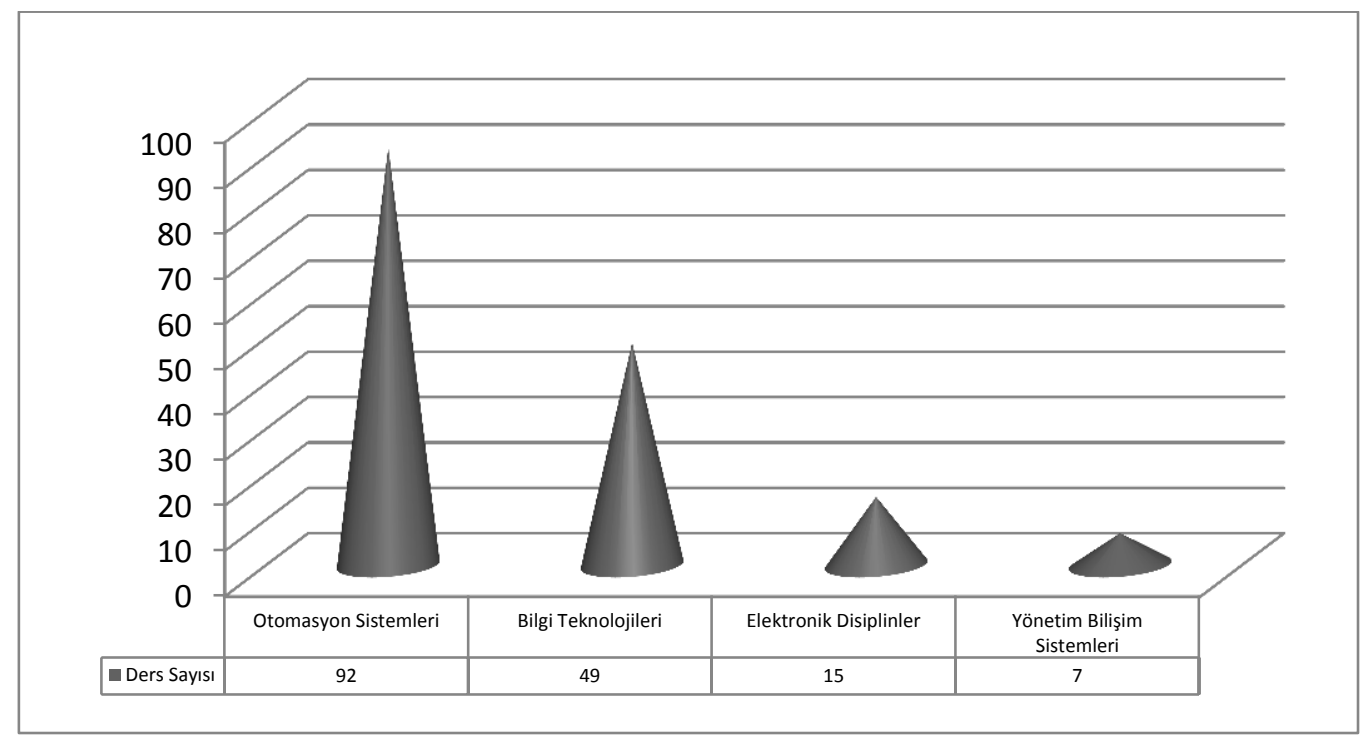

Tablo 1'de bu derslerin program bazlı sayıları gösterilmektedir. Bu çalışmada, araştırma etiği çerçevesinde üniversitelerin isimleri saklı tutulmuştur. Her bir program "P" kodu ve kod numarası ile gösterilmiştir. 163 dersin 49 tanesi "bilgi teknolojileri", 7 tanesi "yönetim bilişim sistemleri", 15 tanesi "elektronik disiplinler" ve 92 tanesi "otomasyon sistemleri" dersleridir.

Tablo 1: Programlarda Teknoloji Derslerinin Dağılımı

\begin{tabular}{|l|l|l|l|l|c|l|l|l|l|l|l|}
\hline KOD: & BT & YBS & ED & OS & Toplam & KOD: & BT & YBS & ED & OS & Toplam \\
\hline P1 & 1 & - & 1 & 2 & 4 & P21 & 2 & - & - & 1 & 3 \\
\hline P2 & 3 & - & - & 2 & 5 & P22 & 1 & - & - & 2 & 3 \\
\hline P3 & 2 & - & - & 6 & 8 & P23 & - & - & 1 & 2 & 3 \\
\hline P4 & - & - & - & 2 & 2 & P24 & 1 & - & - & 2 & 3 \\
\hline P5 & 1 & - & 1 & 1 & 3 & P25 & 1 & - & 1 & 3 & 5 \\
\hline P6 & 2 & 1 & - & - & 3 & P26 & 1 & - & - & 2 & 3 \\
\hline P7 & 3 & - & - & 2 & 5 & P27 & 1 & - & - & 1 & 2 \\
\hline
\end{tabular}


Tablo 1'in devamı

\begin{tabular}{|l|l|l|l|l|l|l|l|l|l|l|l|}
\hline P8 & - & - & - & 2 & 2 & P28 & 2 & - & 1 & 5 & 8 \\
\hline P9 & 2 & 1 & 1 & 1 & 5 & P29 & 2 & - & 1 & 2 & 5 \\
\hline P10 & 1 & 1 & 2 & 1 & 5 & P30 & 1 & - & - & 3 & 4 \\
\hline P11 & 2 & 1 & 1 & 2 & 6 & P31 & 1 & - & 1 & 1 & 3 \\
\hline P12 & - & 1 & - & 2 & 3 & P32 & 1 & - & - & 3 & 4 \\
\hline P13 & 1 & 1 & 1 & 3 & 6 & P33 & - & - & - & 5 & 5 \\
\hline P14 & 2 & - & - & 2 & 4 & P34 & 2 & - & - & 2 & 4 \\
\hline P15 & 2 & - & 1 & 2 & 5 & P35 & 2 & - & - & 4 & 6 \\
\hline P16 & - & 1 & - & 2 & 3 & P36 & 2 & - & - & 1 & 3 \\
\hline P17 & 1 & - & - & 2 & 3 & P37 & 2 & - & - & 6 & 8 \\
\hline P18 & 2 & - & 1 & 6 & 9 & P38 & - & - & 1 & 2 & 3 \\
\hline P19 & 1 & - & - & 2 & 3 & Toplam & 49 & 7 & 15 & 92 & 163 \\
\hline P20 & 1 & - & - & 3 & 4 & Ortalama & 1,28 & 0,18 & 0,39 & 2,42 & 4,28 \\
\hline
\end{tabular}

Tablo 1'de görüldüğü üzere bir lisans programı toplamda 9 ders ile en fazla sayıda dersi önermektedir, üç üniversite ise toplamda ikişer ders ile en az sayıda dersi sunmaktadır. Programlarda önerilen ders sayısı ortalaması ise 4,28'dir. Toplamda 24 program, 4 ve daha az sayıda ders içermekte, 14 program ise 5 ve daha fazla sayıda ders içermektedir.

Derslerin türlerine bakıldığında bilgi teknolojileri dersleri arasında 37 zorunlu, 11 seçmeli ders olduğu belirlenmiştir. Bir dersin türü belirtilmemiştir. Yönetim bilişim sistemleri derslerinin 1'i zorunlu, 6'sı seçmelidir. Elektronik disiplinler derslerinin 1'i zorunlu, 13'ü seçmelidir. Bu kategoride iki dersin türü belirtilmemiştir. Otomasyon sistemleri derslerinin 31'i zorunlu, 54'ü seçmelidir. Programlarda toplam 7 dersin türü belirtilmemiştir. Bu veriler, bilgi teknolojileri ve otomasyon sistemleri derslerinin en büyük zorunlu ders kategorilerini oluşturduğunu, elektronik disiplinler ve yönetim bilişim sistemleri derslerinin ise sayıca az olduğunu ve çoğunlukla seçmeli ders statüsünde sunulduğunu göstermektedir.

Kategoriler incelendiğinde program başına düşen "bilgi teknolojileri" derslerinin ortalamasının 1,28 olduğu anlaşılmaktadır. Toplamda 2 programda 3 ders, 14 programda 2 ders, 15 programda 1 ders sunulmuş, 7 programda ise hiç ders sunulmamıştır. Bu çalışma kapsamında incelenen bilgi teknolojileri dersleri, temel bilgi teknolojileri ve web/medya tasarımı derslerini içermektedir. Genellikle lisans birinci sınıflarda okutulan temel bilgi teknolojileri türü dersler aracılığıyla öğrencilerin bilgisayarlar konusunda bilgi edinmeleri; bilgisayar yazılımı ve donanımı ile iletişim cihazlarını anlamaları; bilişim teknolojilerinde kullanılan teknolojik unsurları ve özelliklerini anlamaları; özellikle ofis otomasyon sistemleri olan kelime işlemcileri, elektronik hesap tabloları ve veri tabanı programları ile uygulamalar geliştirebilmeleri amaçlanmaktadır.

Yönetim bilişim sistemleri kategorisindeki dersler, diğer gruplarla kıyaslandığında sayıca çok azdır. "Yönetim bilişim sistemleri" derslerinin ortalaması 0,18 'dir. Toplamda 7 programda 1 ders sunulmuş, 31 programda ise hiç ders sunulmamıştır. Bu dersler örgüt, yönetim ve bilgi sistemi ilişkisi, bilişim teknolojileri altyapısı, üst düzey yönetici destek sistemleri, karar destek sistemleri, yönetim bilişim sistemleri, kurumsal sistemler ve benzeri başlıklar ile veri tabanı yönetimi konuları üzerine odaklanmaktadır. İlgili dersler turizm işletmelerinin intiyaç duyduğu bilgi sistemlerinin teknik ve yönetimsel özelliklerini anlayabilmek gibi önemli öğrenim 
çıktılarına sahiptir. Dördüncü sanayi devrimi ile birlikte işletmelerde bilgi sistemleri büyük bir dönüşüm yaşamaya başlamıştır (Schwab, 2016). Turizm endüstrisindeki işletmeler de bu değişim hızına mutlaka ayak uydurmak zorundadır. Dijital dönüşüm ve Endüstri 4.0 'a dair kavramlar ders içeriklerine mutlaka dâhil edilmelidir.

"Elektronik disiplinler" derslerinin ortalaması 0,39'dur. Toplamda 1 programda 2 ders, 13 programda 1 ders sunulmuş, 24 programda ise hiç ders sunulmamıştır. Elektronik disiplinler kategorisinde e-ticaret, e-pazarlama ve e-turizm isimli dersler bulunmaktadır. Daha çok seçmeli olarak okutulan bu derslerin amacı, Internet ve Web teknolojilerine, web uygulamalarına ve mobil uygulamalara dayalı iş süreçlerini yürüten işletmelerin teknolojik standartlarını ve altyapılarını anlatmak, ürün ve hizmet sunumunda teknolojiyi kullanarak nasıl strateji geliştirilebileceğini ve katma değer yaratılabileceği öğretmektir. Bu derslerin bazılarında elektronik ticaret kavramının turizmi nasıl etkilediği anlatılmaktadır. Elektronik ticaret, turizmi derinden etkileyen bir gelişme olduğundan, turizm öğrencilerinin mezun olmadan önce bu gelişmenin farkında olması, elektronik ticaret ile ilgili gerekli bilgi ve becerileri edinmesi gerekmektedir (Busby ve Huang, 2012).

"Otomasyon sistemleri" derslerinin ortalaması 2,42'dir. Toplamda 11 program 2'den fazla sayıda ders içermekte, 26 program ise 2 ve daha az sayıda ders içermektedir. Bir program ise hiç otomasyon dersi içermemektedir. En fazla sayıda ve çeşitte dersin bulunduğu son kategoride yer alan uygulamalı otomasyon dersleri konaklama, seyahat ve havayolu, yiyecek-içecek, kalite yönetimi, maliyet ve muhasebe otomasyonlarını içermektedir. Bu dersler, öğrencilerin kariyerlerine başladıktan sonra otomasyonları zorluk çekmeden kullanabilmesini amaçlamaktadır. Bu kategoride konaklama otomasyonu alt kategorisinde otel otomasyonları ve önbüro otomasyonları olmak üzere iki temel ders kategorisi bulunmaktadır. Otel ya da konaklama işletmeleri otomasyonu adı altındaki bazı derslerin içerikleri sadece önbüro modülünün öğretilmesine yönelik iken bazı dersler kat hizmetleri gibi farklı modüllerin de öğretilmesini hedeflemektedir. En çok öğretilen konaklama otomasyonları Opera, Fidelio ve Elektra'dır. Bazı derslerde bu programlardan bir kaçı birlikte öğretilmektedir. Yine bu kategori altında yer alan seyahat ve havayolu otomasyonuna yönelik dersler, bilgisayarlı rezervasyon sistemlerinin kullanılması, biletleme işlemlerinin öğretilmesine yöneliktir. Bu çerçevede Amadeus, Galileo gibi programlardan biri veya bir kaçı öğretilmektedir.

\subsection{Görüşmelerden Edinilen Bulgular}

Araştırmanın ikinci kısmında akademisyenlerle yapılan görüşmelerde, araştırmanın ilk aşamasının bulgularını değerlendiren katılımcılar etkili öğrenme çıktılarına ulaşmanın önündeki kısıtların yanı sıra beklentilerini ve önerilerini de net bir şekilde ortaya koymuşlardır.

\subsubsection{Algılanan Kısıtlar}

Teknoloji derslerinin sayısı, çeşidi ve niteliği üzerinde kısıtlayıcı role sahip faktörler arasında maddi ve fiziksel kısıtılıklar özellikle vurgulanmıştır. Turizm işletmeciliği eğitiminin daha etkili sonuçlar verebilmesi için sektör ve turizm işletmeciliği programları arasında işbirliğinin artması gerekmektedir. Görüşmelerde bazı katılımcılar, yazılım programlarının fiyatlarına dikkat çekmiştir. Bu durum şöyle ifade edilmiştir:

"Mesela çok güzel bir menü hazırlama programı var. Bu programın tek tek tüm bilgisayarlara yüklenmesi gerekiyor. Ama bu programın tek kullanımlığı 300 
dolar bazında. 36 çarpı 300 dediğimizde çok büyük bir meblağ oluşuyor. O nedenle demo programlarla yetinmek durumunda kalıyoruz. Bu tüm özelliklerin [program özellikleri] açık olmaması demek. Bu da tabi kısıtııor".

Katılımcı 12

Bazı katılımcılar kurumlardaki dersliklerin fiziksel kapasitesinin sınırlı olabildiğini ve laboratuarlardan sorumlu bilgi işlem çalışanlarının sayıca az olduğunu vurgulamıştır. Bu kısıtlılıklar şöyle ifade edilmiştir:

"Devletin olanakları malum. Siz laboratuvar olarak buna hizmet verebilecek misiniz ya da kaç kişiye verebileceksiniz ve kaliteli eğitim verebilecek misiniz? Tabi bunları çok mümkün görmüyorum ben”.

Katılımcı 7

"Aynı zamanda teknik eleman da yok, onu da söyleyeyim. Örneğin, benim dersim için bilgisayar [yazııım] yüklemelerini kendim yaptım. Benim işim değil aslında, benim işim onu anlatmak ama ben yükledim, ben kurdum”.

Katılımcı 13

Dikkat çeken diğer kısıtlılıklar arasında teknoloji derslerini verebilecek uzman öğretim elemanlarının sayıca az oluşu, mevcut yasal düzenlemeler içinde sektörden kişilerin bu dersler için görevlendirilmesinin mümkün olmayışı/sınırlı oluşu ve disiplinler arası işbirliğinin sınırlı oluşu sıralanmıştır. Bu durumu açıklayan iki katıımcının görüşleri aşağıda belirtildiği gibidir:

“...Turizmde çoğunlukla insanlar belirli alanlarda yoğunlaşıyorlar, fakülte içerisinde ise işletmeden destek almak, diğer bölümlerden destek almak, üniversitenin varsa bilgisayar bölümünden destek almak geçerli olabilir. Ama çok kendi başına kalmış turizm bölümlerinde, bilgisayar bölümü olmayan, işletme bölümü olmayan bölümlerde bu dersleri verebilecek kalifiye eleman olduğunu zannetmiyorum ben".

Katılımcı 9

Katılımcılardan bazıları mevcut teknoloji derslerinin güncellenmesi, yeni gelişmelerin daha yakından takip edilmesi, sektörle etkin bir iletişim halinde olunması, teknoloji üzerine kişisel bilgi birikiminin artırılması gibi çalışmalar üzerinde zaman faktörünün kısıtlayıcı etkisine değinmiştir:

"Bir şeyleri yapmak istiyorsunuz ama bazen vakit bulamayabiliyorsunuz. Başka şeyler giriyor işin içine. Sadece ders vermek değil, başka işler var, kendi çalışmalarımız var, idari görevler var. İs yaşam dengesi diyoruz. lyi kötü bir özel hayatımız var. ...En önemli sebep bu, zaman kısıtımızın olması. Bazen gelişmeleri kaçırabiliyoruz. Kendi alanımızda bile olsa".

Katılımcı 11

Katılımcılardan bazıları yaş faktörünün teknoloji algısı ve teknoloji kullanma becerisi ile ilişkisine işaret etmiştir. Teknolojinin ayrı bir ders olarak ya da işletme fonksiyonlarına yönelik dersler içerisinde ne ölçüde ve nasıl anlatıldığının, dersi veren öğretim elemanının yaşı ile ilişkisi katılımcılar tarafından şöyle ifade edilmiştir. 
"Dersleri veren hocaların kuşaklarına baktığın zaman daha çok $X$ kuşağı. $Y$ kuşağı yeni yeni [ders veriyor]. Teknofobi denen bir şey var bizim kuşaklarda. Teknofobik olan bir jenerasyonun teknoloji anlatması kadar komik bir şey yok".

Katılımcı 10

\subsubsection{Beklentiler ve Öneriler}

Katılımcılara teknoloji derslerinin sayısı, çeşidi ve niteliği konusundaki beklentileri ve önerileri sorulmuştur. Cevaplar, müfredat ve öğretim elemanına yönelik beklentiler başlıklarıyla incelenmiştir.

\subsubsection{Müfredatlar}

Görüşmelerde katılımcılar teknoloji ile bağlantılı program çıktıları oluşturulması gerektiğini vurgulamıştır. Sektör temsilcilerinin ve diğer disiplinlerden uzmanların görüşlerinin de ders planları oluşturulurken göz önünde bulundurulmasının faydalı olacağını ifade eden bazı ifadeler şöyledir:

"Sadece teori bazlı kalmayıp, uygulamada bunların [nasıl] gerçekleştiği [anlaşılmalı]. Dolayısıyla, öğrencilere bir takım yetkinlikler kazandırmanın gerekli olduğu konusunda [bir görüş var]. O nedenle program çıktıları ve ders çıktıları arasında bence teknolojinin de daha fazla gündeme getirilmesi lazım diye düşünüyorum".

Katılımcı 10

"Mesela yoğun teknolojik disiplinlerle iletişimde olunabilir. Diğer teknoloji bölümleri ile [birlikte] derslerin içerikleri belirlenebilir. Sadece sektör ile değil. Çünkü belki sektörün de geride kaldığı uygulamalar vardır”.

Katılımcı 1

Katılımcılara ilk çalışmanın bulguları gösterildikten sonra, mevcut durumu değerlendirmeleri istenmiştir. Katılımcılardan bazıları teknoloji derslerinin öğrenim ve iş hayatındaki yeri ile yönetim bilişim derslerine yönelik intiyacı şöyle belirtilmiştir:

"Temel bilgi teknolojileri sorununu daha çözememişiz. Öğrenci bize geldiğinde Word'ü de, Excel'i de düzgün kullanamaz vaziyette geliyor. Öncelikle onları öğretmek gerekiyor. Bu derslerin hemen hemen bütün bölümlerde verilmesinin temel nedeni sanırım o. Öğrencinin üniversiteye adapte olabilmesi için öncelikle o sistemleri öğrenmesi lazım. Uygulamaların anlatılması ise biraz piyasaya [sektöre] yönelik. Piyasada şu programlar kullanılıyor, öğrenci mezun olduğu zaman bunları bilmesi lazım. Ama belki de yönetim bilişim sistemlerinin ve diğer karar destek sistemlerinin en azından mantığının anlatılması lazım. Gelecekte, özellikle yönetim aşamasında en çok kullanılanlar aslında bunlar. Hani stratejik kararlar verilecek, planlar hazırlanacak. Eğer bir yönetici adayı yetiştiriyorsak, [bunlar] bilmesi gereken şeyler. Belki otomasyonu çok daha kısa sürede öğrenir ama bu sistemleri teorik bilgiler ile harmanlamayı öğrencilerin okul aşamasında öğrenmesi lazım. Belki ağırlığı biraz daha buraya kaydırmak gerekiyor".

Katılımcı 11

Katılımcılardan bazıları, turizm sektörüne yönelik geliştirilmiş olan pek çok yazılım programı bulunduğunu belirtmiştir. İlgili alandaki öncü programlardan birini öğrenmenin, benzer ara yüzlere sahip diğer programları öğrenmeyi kolaylaştırdığı şöyle açıklanmıştır: 
"Bizim kullandığımız program piyasanın en üst versiyon programı, en kapsamlı programı. Bu programı a'dan z'ye öğrettiğinizde, diğer programlara entegrasyonu zaten çok kolay oluyor öğrencinin. Biz en ufak detayına kadar öğretiyoruz".

Katılımcı 12

Yapılan görüşmelerde katılımcılardan biri zorunlu stajların, otomasyon programının fonksiyonlarını daha iyi kavrayabilmek için önemli bir fırsat olduğunu şu sözlerle vurgulamıştır:

"Kesinlikle olumlu anlamda çok etkili [stajlar]. Mesela biz burada laboratuvar ortamındayız. Biz o programı kullanma becerisini öğrensek de doğrudan iş ortamının stresinde, doğrudan turistlerle, konuklarla, müşterilerle birebir iletişim halindeyken o programı kullanmak ayrı bir beceri gerektiriyor".

Katılımcı 2

Görüşmelerde bazı katılımcılar, Excel programının iş hayatı için çok gerekli olduğunu, bu programın kullanımının ileri seviyede öğretilmesi gerektiğini belirtmişlerdir. Bu görüşe örnek bir ifade aşağıda belirtildiği gibidir:

"Dış dünyada, hangi iş kolunda olursa olsun, turizm içinde de dışında da, farklı sektörlerde de mutlaka çok iyi düzeyde Excel bilinmesi lazım. Işsler Excel üzerinden gidiyor. Programlar, raporlar, hesaplamalar, formüller bu eksik var. En çok kullanılacak bu olacak. Biz bunu okulda verirsek, onlar artı bir ile başlar. Bir konuk konuşmacım, teknolojiye ilgisi olan, ofis programlarına çok vakıf olan bir kişiydi, şunu söylemişti: "Formül yazdığım zaman bana uzaydan gelmişim gibi bakıyorlardı". Bu cümle aslında pek çok şeyi ifade ediyor".

Katılımcı 12

Katılımcılara, müfredatlara teknik derslerin eklenmesi gerekli midir diye sorulduğunda iki farklı görüş ortaya çıkmıştır. Bu görüşlerden ilki, turizm öğrencilerinin konunun teknik kısmına odaklanan derslere ihtiyacı olmadığı, bu konuları kendi uzmanlarına bırakmanın daha uygun olacağı yönündedir:

"Turizm öğrencisinin bence web sitesi tasarımında uzmanlaşması gerekmiyor. Sadece nasıl yapıldığını teorik olarak bilir, müşterinin ilgisini çekmesi için içeriğin ne olması gerektiği hakkında bilgiye sahip olur, teknik kısmını başkasına yaptırabilir. Herkesin her işte uzmanlaşması gerekmiyor. Çağın gerekleri bunlar. Ben her işi yapabilirim diye bir şey yok. Yönetici olacaksa [gelecekte], otelin web sitesinde ne olması gerektiğini bilmek zorunda. Bunun nasıl olması gerektiğini bilmeli mi, bence bilmesi gerekmiyor".

Katılımcı 11

Diğer taraftan, görüşmelerden bazılarında ise katılımcılar "web sitesi tasarımı" dersi örneği üzerinden yaptıkları yorumlarda, bu tür teknik derslerin turizm öğrencileri için gerekli olmadığı konusundaki görüşlere katılmadıklarını belirtmiş ve nedenlerini şöyle açıklamışlardır:

"Eskiden bir konu hakkında uzmanlığa sahip olmanız belirli bir pozisyona gelmenizi sağlıyordu. Şimdi öyle değil. Ne kadar çok alanda bilgi ve beceriye sahipseniz, iş bulabilme olasılığınız artıyor. Bilgi ve becerilerimizi her anlamda geliştirmemiz lazım. Turizm her alandan az veya çok bilgi sahibi olmanızı gerektiriyor. Biz temelini vermeliyiz ki, öğrenci üzerine çıkabilsin”. 
Katılımcı 12

"Sonuçta, bu [bir] artı. Yüz tane turizm [bölümü] mezunu insan olduğunu düşün. Bunun beş tanesi web[sitesi]tasarlamayı bilerek çıktığı [mezun olduğu] zaman bir adım diğerinin önüne geçiyor. Sonuçta konunun uzmanı, uzay boşluğundan gelmiyor ki. Artı, turizm öğrencisinin onu yapması daha iyi çünkü onun başka bir gözü var. Onun web tasarımı çok daha iyi olabilir para için web tasarımı yapan bir insandan. Turizm öğrencisinin çok daha iyi yapma ihtimali var, o teknolojiyi kullanmayı bildiği sürece. Çünkü onun başka bir gözü var, turizm işletmecisi gözüyle bakıyor".

Katılımcı 13

Katılımcılardan bazıları ders çeşitliliğinin sınırlı kaldığı durumlarda öğrencilerin diğer bölümlerin serbest seçimlik havuzundaki derslerine yönlendirilebileceğini ifade etmiştir:

"Şöyle de bir şey var: Bologna [sistemi] ile [gelen] serbest seçimlik derslerin mantığı, öğrencilerin ilgilerinin olduğu alanda kendilerini yetiştirme şansının tanınmasıydı".

Katılımcı 10

\subsubsection{2. Öğretim Elemanının Özellikleri}

Yapılan görüşmelerde katılımcılardan biri, teknoloji ile ilişkili derslerin niteliklerini belirli bir standardın üstünde tutabilecek öğretim elemanlarının özelliklerini şöyle ifade edilmiştir:

"Teknolojiye çok yatkın olması gerekiyor. Kullanım alanına ait bir sertifika eğitiminden geçmiş olması gerekebilir diye düşünüyorum. Eğer çok fazla teoriye dönük bir ders ise, pratik uygulaması olmayan bir ders ise sahadan farklı bilgileri edinip öğrencilere kazandırabilecek nitelikte olmalı. Açık görüşlü, teknolojiyi çok yakından takip eden ve olası program değişikliklerini çok çabuk fark edebilen ve biraz da geleceği öngörebilen bir karakter olması gerekiyor. Çünkü hiç tahmin etmediğimiz program dilleri birkaç sene içinde çok önemli programlarda kullanılabiliyor. Bir şey olmadan önce onu tahmin edebilecek bir vizyonda olması gerekiyor diye düşünüyorum".

Katılımcı 7

Bir katılımcı, fakülte yönetimlerinin, öğretim elemanlarının teknoloji eğitimlerine katılmalarını teşvik etmeleri gerektiğini şöyle vurgulamıştır:

"Bir program eskiyor ve yerine yenisi geliyor ya da bir programa farklı özellikler ekleniyor. Bu açıdan kendilerini geliştirebilirler... Mesela özel sektörde nasıl çalışanları ücretsiz Excel eğitimine gönderiyorlar, aynı şekilde okul da hocalarını göndermeli”.

Katılımcı 5

Katılımcılardan biri, turizm sektöründe kullanılan otomasyon programlarını tedarik eden bazı firmaların, öğretim elemanının gerekli sertifikaları alması halinde programın fakültede ücretsiz kurulumunu sağladığını belirtmiştir:

"Biz ücret ödemiyoruz. X programının Türkiye'de sağlayıcısı olan firma, Türkiye'de turizm istihdamını destekleme projesi kapsamında kullanma 
sertifikasına sahip ders veren hocaların olduğu kurumlarda bu programın ücretsiz kullanılmasını sağlıyor".

Katılımcı 12

Bazı katılımcılar sektörle geliştirdiği ilişkilerin, ihtiyaçları belirlemek; otomasyon firmaları ile geliştirilen ilişkilerin güncellemelerden ve fırsatlardan haberdar olmak, kurulum ve sonrasındaki süreçte destek almak; bilgi işlem birimleri ile geliştirilen ilişkilerin ise aksaklıkları kısa sürede gidermek için gerekli olduğunu vurgulamıştır. Bu görüşlerden biri aşağıdaki gibi ifade edilmiştir:

"X [öğretim elemanının ismi] hocanın gittiği gibi kursa [sertifika eğitimi] gitmesi gerekiyor. O kursta edindiği network [çevre] ile sürekli iletişim içerisinde olması gerekiyor. O programı sağlayan kurum ile bağlantıda olması gerekiyor. O kurum burada Y'yi anahtar kişi olarak bilmeli ve bir şey olduğu zaman onunla temasa geçmeli".

Katılımcı 9

$\mathrm{Bu}$ bölümde yer verilen görüşler doğrultusunda, algılanan tüm kısıtlar ile beklentiler ve öneriler Tablo 2'de bütünsel bir yaklaşım ile sunulmuştur.

Tablo 2: Katılımcıların Algıladığı Kısıtlar, Beklentileri ve Önerileri

\begin{tabular}{|c|c|c|}
\hline \multirow{2}{*}{ KISITLAR } & \multicolumn{2}{|c|}{ BEKLENTILER VE ÖNERILER } \\
\hline & Müfredata Yönelik & Öğretim Elemanına Yönelik \\
\hline $\begin{array}{l}\text { - Maddi kaynakların kısıtlı olması, } \\
\text { bazı yazılım ve donanım } \\
\text { kaynaklarına erişimi güç hale } \\
\text { getirmektedir. } \\
\text { • Bilgisayar laboratuvarlarının } \\
\text { kapasitesinin sınırlı olması dersi } \\
\text { alabilecek öğrenci sayısı } \\
\text { üzerinde kısıtlayıcı olmaktadır. } \\
\text { Bilgi işlem faaliyetlerinden } \\
\text { sorumlu görevlilerin sayıca az } \\
\text { oluşu, teknik problemlerin } \\
\text { çözümünün uzamasına neden } \\
\text { olmaktadır. } \\
\text { - Turizmde teknoloji alanında } \\
\text { uzmanlaşmış sınırlı sayıda } \\
\text { akademisyen bulunmaktadır. } \\
\text { Mevcut yasal düzenlemeler } \\
\text { kurum dısından uzmanların ve } \\
\text { sektör temsilcilerinin ders verme } \\
\text { amacıyla görevlendirilmesine izin } \\
\text { vermemekte ya da kısıtlamalar } \\
\text { getirebilmektedir. Disiplinler arası } \\
\text { işbirliği de etkin şekilde } \\
\text { gerçekleştirilememektedir. Tüm } \\
\text { bu durumlar, donanımlı öğretim } \\
\text { elemanlarına ulaşmayı } \\
\text { güçleştirmektedir. }\end{array}$ & $\begin{array}{c}\text { - Ders planları, sektörün ve } \\
\text { teknoloji uzmanlarının } \\
\text { görüşleri doğrultusunda } \\
\text { güncellenmelidir. } \\
\text { • Staj yapan öğrencilerden } \\
\text { teknoloji kullanımı konusunda } \\
\text { geribildirim alınmalı, ders } \\
\text { içerikleri gözden } \\
\text { geçirilmelidir. } \\
\text { • Öğrencilerin ilgi alanlarına ve } \\
\text { kariyer hedeflerine yönelik } \\
\text { seçimlik dersler sunulmalıdır. } \\
\text { • İleri seviye Excel programı } \\
\text { kullanımı öğretilmelidir. } \\
\text { Uzmanlık gerektiren alanlarda } \\
\text { en azından genel bilgi } \\
\text { verilmelidir. } \\
\text { • Öğrenciler bölüm dışı } \\
\text { seçimlik derslerini } \\
\text { uzmanlaşmak istediği alana } \\
\text { yönelik seçmelidir. }\end{array}$ & $\begin{array}{l}\text { - Teknoloji ile bağlantılı dersleri } \\
\text { veren öğretim elemanları } \\
\text { sektörle bağlantılı olmalıdır. } \\
\text { - Teknoloji ile bağlantılı dersleri } \\
\text { veren öğretim elemanları } \\
\text { teknoloji konusuna ilgi duymalı } \\
\text { ve güncel gelişmeleri sıkıca } \\
\text { takip etmelidir. } \\
\text { - Teknoloji ile bağlantılı dersleri } \\
\text { veren öğretim elemanları } \\
\text { anlattıkları konuları } \\
\text { örneklendirebilmeli, teorik bilgiyi } \\
\text { pratiğe dökebilmelidir. } \\
\text { - Otomasyon derslerini veren } \\
\text { öğretim elemanları, öğrettikleri } \\
\text { programı kullanma becerisini } \\
\text { gösteren bir sertifikaya sahip } \\
\text { olmalıdır. Uygulama esnasında } \\
\text { oluşan sorunları kolayca } \\
\text { çözebilmelidir. } \\
\text { - Otomasyon derslerini veren } \\
\text { öğretim elemanları, program } \\
\text { sağlayıcısı firma ile iletişsim } \\
\text { haline olmalıdır. }\end{array}$ \\
\hline
\end{tabular}


Tablo 2'nin devamı

- Akademi ve sektör arasında yakın bir ilişki ve iletişim ağı bulunmamaktadır. Öğretim elemanları, akademik ve idari iş yükü nedeniyle sektörel ve teknolojik gelişmeleri takip edebilmek için yeterince zaman bulamamaktadır.

- X kuşağından olan öğretim elemanlarının teknolojiyi kullanma korkusu, derslere bu konunun entegre edilmesini zorlaştırabilmektedir.

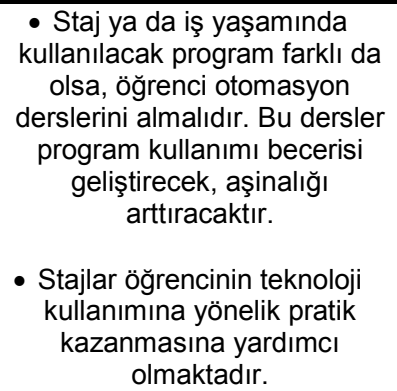

- Staj ya da iş yaşamında kullanılacak program farklı da olsa, öğrenci otomasyon derslerini almalıdır. Bu dersler program kullanımı becerisi geliştirecek, aşinalığı arttıracaktır.

- Stajlar öğrencinin teknoloji kullanımına yönelik pratik kazanmasına yardımcı olmaktadır.

- Teknoloji derslerini veren öğretim elemanları teorik bilginin pratiğe nasıl aktarıldığını öğretebilmek için uzman konuk konuşmacıları derslerine davet etmelidir.

- Otomasyon derslerini veren öğretim elemanları, kurum içinde ilgili birimlerin yetkilileri ile etkili iletişim halinde olmalıdır.

\section{Sonuç ve Öneriler}

Bu çalışmada, Türkiye'deki turizm işletmeciliği lisans programlarının ders planlarında yer alan teknoloji konulu dersleri belirlemek, içeriklerini incelemek, mevcut durumu belirlemek amaçlanmıştır. Bu doğrultuda bir analiz gerçekleştirilmiş, elde edilen bulgular akademisyenlerin görüşlerine sunulmuştur. Teknoloji derslerinin sayısını, çeşidini ve niteliğini etkileyebilecek kısıtlar, beklentiler ve öneriler akademisyenler tarafından değerlendirilmiştir.

$\mathrm{Bu}$ araştırmanın iki önemli çıktısı bulunmaktadır. Bunlardan ilki, turizm işletmeciliği lisans programlarında teknoloji ile ilişkili dört temel ders kategorisi olduğu yönündedir. Bu kategoriler, temel bilgi teknolojileri, yönetim bilişim sistemleri, elektronik disiplinler ve otomasyon sistemleri şeklinde belirlenmiştir. Ders sayısı açısından en zengin kategoriler temel bilgi teknolojileri ve otomasyon sistemleridir. Temel bilgi teknolojileri dersleri diğer teknoloji dersleri için altyapı oluşturmaktadır. Otomasyon sistemleri dersleri ise öğrencilerin iş süreçlerine kolay ve hızlı bir şekilde adapte olmalarını sağlamaktadır. Bilgihan ve arkadaşlarının (2014: 328-332) araştırma bulguları temel bilgi teknolojilerini kullanabilme/yönetebilme becerisinin sektör temsilcileri tarafından önemli olarak algılandığını göstermektedir. Lashley ve Rowson (2005)'un bulguları ise bilgi teknolojilerin hem sayısal hem de sözel yönleriyle temel beceriler arasında görüldüğünü ortaya çıkarmıştır. Bu çalışmanın bulguları, Türkiye'de müfredatların temel bilgi teknolojilerine yönelik ihtiyacı karşılayacak şekilde hazırlanmış olduğunu göstermektedir.

Elektronik disiplinler dersleri diğer iki kategoriye kıyasla sayıca oldukça azdır. Ders kategorileri arasında sayıca en küçük grubu ise yönetim bilişim sistemleri dersleri oluşturmaktadır. İnternetin yönetim fonksiyonları ile bütünleştirilmesi ve işletme stratejileri üzerindeki etkilerini anlamaya ve içselleştirip pratiğe dökme becerisi kazanmaya yardımcı olan elektronik disiplinler dersleri ve yönetim bilişim sistemleri dersleri büyük önem arz etmelerine karşın müfredatlarda ağırlık verilmeyen iki alan olarak belirlenmiştir.

Araştırmanın ikinci önemli bulgusu, akademisyenlerin teknoloji derslerine yönelik algıladığı kısıtlar, beklentiler ve öneriler ile ilgilidir. Çalışmanın bulguları bir bütün olarak değerlendirildiğinde, müfredatlarda yer alan teknoloji derslerinin sayısı, çeşidi ve niteliği üzerinde etkili olan kısıtılıklar, maddi ve fiziksel kaynaklar ile teknik personel sayısının sınırlı oluşu, mevcut bazı yasal düzenlemeler, turizm işletmeciliği programlarında teknoloji alanında uzman öğretim elemanlarının sayıca az oluşu, iş yükü ile bağlantılı zaman kısıtılığı, bazı öğretim elemanlarının yaş faktörüne bağlı olarak yeni teknolojilere aşina olmaması ve teknoloji korkusu yaşamalarıdır. 
Yöneticilerin ve öğretim elemanlarının, bu kısıtların farkında olarak önlem almaları gerekmektedir.

Müfredatlara yönelik beklentiler, sektör temsilcileri ve diğer disiplinlerde çalışan teknoloji alanından uzman kişilerin ders planlarının oluşturulma sürecine katılmasını sağlamak, yönetim bilişim ve elektronik disiplinler ders kategorilerini müfredata etkin bir şekilde entegre etmek, sektörün intiyaçları da tespit edildikten sonra müfredatlara yeni dersler eklemek, öğrencileri ilgi alanlarına yönelik serbest seçimlik derslere yönlendirmek şeklindedir. Bu beklentilerin yöneticiler ve bölüm öğretim elemanları ile paylaşıması, eğitim kalitesini artırmak için önem taşımaktadır.

Hem sektör deneyimi ve bilgisi olan hem de bilgi teknolojileri konusunda uzman olan eğitimciler, öğrencilerin gelişimini olumlu olarak etkileyebilmektedir (Lashley ve Rowson, 2005). Bu çalışmada, sektör deneyiminin zamanla güncelliğini yitirebileceği nedeniyle, sektörle ve yazılım firmalarıyla dinamik bir iletişim yaratılması gerekliliği vurgulanmıştır. Bu tür bir iletişimin bazı kısıtları ortadan kaldırmak gibi etkileri olabilmektedir. Lashley ve Rowson (2005)'ın belirttiği üzere sektöre özgü yazılımların yüksek fiyatları karşısında bazı okullar çözümü endüstri ile ortaklık kurmak ve işyeri ziyaretleri şeklinde çözümler yaratmaktadır. Benzer şekilde öğretim elemanları, bazı yazılım firmalarının üniversitelere sunduğu fırsatları yakından takip etmekte ve öğretici sertifikalarını alarak ücretsiz kullanım hakkından faydalanılmasını sağlamaktadır.

Turizmde bilgi teknoloji eğitimleri genel ve uzmanlaştırılmış ders modülleri aracılığıyla verilmektedir (Buhalis, 1998). Yakın gelecekte Türkiye'de öğrenciler bilgi teknolojisi bilgisine sahip olarak üniversiteye başlayacaktır. Bu durumda temel bilgi teknolojisi dersinin zorunlu bir ders olarak müfredata eklenmesine gerek kalmayacağı öngörülmektedir. Bu derslerin yerine yönetimsel ihtiyaçlara yönelik dersler müfredatlara dâhil edilecektir.

Turizm, ağırlama ve hizmet akademisinde güncel ve popüler konular arasında yer alan bir konu coğrafi bilgi sistemleridir (Chen, 2007). Turizm işletmeciliği ile doğrudan ilişkili olan korunan alan planlaması, taşıma kapasitesi yönetimi gibi konular için hayati önem taşıyan bu sistemlere dair derslerin müfredatlara eklenmesi gerekmektedir.

Literatürde programlama gibi uzmanlık isteyen konuların turizm öğrencilerinin sahip olması beklenen beceriler arasında olmadığı yönünde görüşler vardır (Buhalis, 1998). Bu çalışmada da benzer bir durum ortaya çıkmıştır. Zorunlu ve seçimlik teknoloji dersleri arasında programlama gibi uzmanlık derslerinin olmadığı belirlenmiştir. Bununla birlikte, Bilgihan ve arkadaşlarının (2014) belirttiği üzere turizm okullarında, bilgi sistemleri yönetimi üzerine alt programlar açılması uzmanlık ihtiyacının karşılanması konusunda fayda sağlayabilir.

Gelecekteki çalışmalarda öğrencilerin, uzmanların ve sektör temsilcilerinin dâhil edildiği bir çalışma farklı paydaş görüşlerinin yansıtılması açısından faydalı olacaktır. Ayrıca, yurtdışındaki üniversitelerde yer alan turizm işletmeciliği programlarının müfredatlarının incelenmesi yeni stratejiler geliştirmeye olanak sağlayacaktır.

\section{Kaynakça}

Akoğlan Kozak, M. (2009), 'Akademik Turizm Eğitimi Üzerine Bir Durum Analizi', Muğla Üniversitesi Sosyal Bilimler Enstitüsü Dergisi, 22, ss.2-20.

Amoah, V.A. ve Baum, T. (1997), 'Tourism Education: Policy Versus Practice', International Journal of Contemporary Hospitality Management, 9(1), ss.5-12. 
Bilgihan, A., Berezina, K., Cobanoglu, C., Okumus, F. (2014), 'The Information Technology (IT) Skills of Hospitality School Graduates as Perceived by Hospitality Professionals', Journal of Teaching in Travel \& Tourism, 14(4), ss.321-342.

Buhalis, D. (1998), 'Information Technologies in Tourism: Implications for the Tourism Curriculum', İçinde D. Buhalis, A.M. Tjoa, J. Jafari (Editörler) Information and Communication Technologies in Tourism, Viyana: Springer ss.289-297.

Buhalis, D. (2008), 'Progress in Information Technology and Tourism Management: 20 Years on and 10 Years After the Internet-The State of Etourism Research', Tourism Management, 29(4), ss.609-623.

Buhalis, D. ve O'Connor, P. (2001), 'Opinion: IT in the Tourism Education Curriculum'. Tedqual/ WTO THEMIS Publication, 3(1), ss.11-14.

Busby, G. ve Huang, R. (2012), 'Integration, Intermediation and Tourism Higher Education: Conceptual Understanding in the Curriculum', Tourism Management, 33, ss.108-115.

Cecil, A. ve Krohn, B. (2012), 'The Process of Developing a Competency-Based Academic Curriculum in Tourism Management', Journal of Teaching in Travel \& Tourism, 12(2), ss.129-145.

Chathoth, P.K. ve Sharma, A. (2007), 'Core Curricular Issues in Hospitality and Tourism Education - Present Structure and Future Directions', Journal of Hospitality \& Tourism Education, 19(1), ss.10-19.

Chen, R.J.C. (2007), 'Geographic Information Systems (GIS) Applications in Retail Tourism and Teaching Curriculum', Journal of Retailing and Consumer Services, 14, ss. 289-295.

Cheung, L. ve Law, R. (2000), 'Industrial Information Technology Applications: Have Hospitality and Tourism Graduates Learned the Needed Skills?', Journal of Hospitality \& Tourism Education, 12(2), ss.19-23.

Daniel, A.D., Costa, R.A., Pita, M. ve Costa, C. (2017), 'Tourism Education: What About Entrepreneurial Skills?', Journal of Hospitality and Tourism Management, 30, ss.65-72.

Elliot, S. ve Joppe, M. (2009), 'A Case Study and Analysis of E-Tourism Curriculum Development', Journal of Teaching in Travel \& Tourism, 9(3-4), ss. 230-247.

Hsu, L. (2012), 'Web 3D Simulation-based Application in Tourism Education: A Case Study with Second Life, Journal of Hospitality', Leisure, Sport \& Tourism Education, 11, ss.113-124.

Lashley, C. ve Rowson, B. (2005), 'Getting IT right: Exploring Information Technology in the Hospitality Curriculum', International Journal of Contemporary Hospitality Management, 17(1), ss.94-105.

Lee, P.C., Sun, S., Law, R. ve Lee, A.H. (2017), 'Educational Technology in Hospitality Management Programmes: Experience and Expectation', International Journal of Tourism Sciences, 17(3), ss.153-164.

Özen, A. ve Zengin, B. (2015), 'Lisans Düzeyinde Turizm Eğitimi Alan Öğrencilerin Bilgisayar Ve Temel Bilgi Teknolojileri Dersine Bakış Açılarının Değerlendirilmesi: Nevşehir Hacı Bektaş Veli Üniversitesi Turizm Fakültesi Örneği', Kastamonu Üniversitesi Iktisadi ve Idari Bilimler Fakültesi Dergisi, 8: ss.125-137.

Penfold, P. (2009), 'Learning Through the World of Second Life-A Hospitality and Tourism Experience', Journal of Teaching in Travel \& Tourism, 8(2-3), ss.139160.

Schwab, K. (2016), Dördüncü Sanayi Devrimi [The Fourth Industrial Revolution, World Economic Forum]. (Z. Dicleli Çev.), İstanbul: Optimist.

Yıldırım, A. ve Şimşek, H. (2006), Sosyal Bilimlerde Nitel Araştırma Yöntemleri, Ankara: Seçkin. 
Yükseköğretim Kurulu (2018), 'YÖK Lisans Atlası', https://yokatlas.yok.gov.tr/lisansbolum.php?b=10208 (29.04.2018)

Zehrer, A. ve Mössenlechner, C. (2009), 'Key Competencies of Tourism Graduates: The Employers' Point of View', Journal of Teaching in Travel \& Tourism, 9(3-4), ss.266-287. 